\title{
THE PROSTHECHEA PRISMATOCARPA COMPLEX (ORCHIDACEAE: LAELIINAE) IN COSTA RICA, WITH A NEW SPECIES, P. TARDIFLORA
}

\author{
FRANCO PUPULIN \\ Jardín Botánico Lankester, Universidad de Costa Rica \\ Research Associate, Marie Selby Botanical Gardens \\ P.O. Box 1031-7050 Cartago, Costa Rica, A.C. - fpupulin@cariari.ucr.ac.cr
}

\begin{abstract}
The complex of Prosthechea prismatocarpa (Orchidaceae: Laeliinae) in Costa Rica is revised. A key to the species of the group is presented, together with their current taxonomy. A new species is described, P. tardiflora Mora-Retana ex Pupulin. The new species may be distinguished within the complex by the abbreviate rhizome, the inflorescence produced on the pseudobulb of the previous year, the non-fragrant flowers, the acute and basally reflexed sepals, the wide isthmus, and the short midlobe of the lip.

Resumen. Se presenta una revisión del complejo de Prosthechea prismatocarpa (Orchidaceae: Laeliinae) en Costa Rica, con una clave de las especies y su taxonomía actualizada. Se describe una nueva especie, P. tardiflora Mora-Retana ex Pupulin. Dentro del complejo, la nueva especie se puede reconocer por el rizoma corto, la inflorescencia producida en el pseudobulbo del año anterior, las flores inodoras, los sépalos agudos y doblados en la base, el istmo del labelo ancho y el lóbulo medio corto.
\end{abstract}

\section{Key Words: Orchidaceae, Prosthechea prismatocarpa complex, Prosthechea tardiflora, Costa Rica}

With their erect, many-flowered inflorescences, Prosthechea prismatocarpa (Rchb.f.) W.E. Higgins and the allied species are among the showiest orchids of Costa Rican flora. Since the time of its original description, the concept of Epidendrum prismatocarpum was used in a broad sense (Reichenbach 1883, 1886, Schlechter 1923, Teuscher 1969, Mora-Retana \& Atwood 1992) to include populations which may be distinguished on the basis of ecological data (Fig. 1,2) and morphological characters (Fig. 3). The need of a careful study of the group was pointed out by Dressler (1993: 58) and new insights were proposed by Mora-Retana and García-Castro (1990), and Pupulin (2001a, 2001b).

The complex of $P$. prismatocarpa as a whole may be recognized by the pyriform, 2- to rarely 3leaved pseudobulbs, the showy flowers produced on long, erect inflorescences, the usually 3-lobed lip (entire in P. brassavolae (Rchb. f.) W.E. Higgins) with the median lobe larger than lateral lobes, acute to attenuate, and the column with large lateral teeth with a deep sinus and a median fimbriate tooth. As presently known, the group is eminently Central American in distribution. With the exception of $P$. brassavolae, ranging north to the States of Oaxaca and Veracruz in Mexico (Espejo Serna \& LópezFerrari 1997), the remaining species of the group are restricted to southern Mesoamerica, with a center of diversity in Costa Rica.

\section{KeY TO THE COSTA RicAN SPECIES OF THE PROSTHECHEA PRISMATOCARPA COMPLEX}

1. Lip entire, without basal lobes P. brassavolae

1. Lip 3-lobed, provided with 2 small lobes at the base .. 2

2. Midlobe of lip cordate-sagittate, caudate; lip $>4 \mathrm{~cm}$ long; sepals and petals unspotted ........P. ionocentra

2. Midlobe of lip triangular, attenuate; lip $<3.5 \mathrm{~cm}$ long; sepals and petals spotted brown ....

3. Inflorescence produced from the pseudobulb of the previous year; rhizome short.... P. tardiflora

3. Inflorescence produced from the new pseudobulb; rhizome elongate 


\section{P. brassavolae}

P. ionocentra

P. neglecta

P. prismatocarpa

P. tardiflora

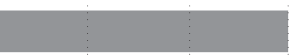

Jan. Feb. Mar. Apr. May Jun. Jul. Aug. Sep. Oct. Nov. Dec.

FIgURE 1. Phenology of the Costa Rican species of Prosthechea prismatocarpa complex.

4. Sepals adaxially papillose; ovary swollen; inflorescence lax. P. neglecta

4. Sepals adaxially glabre; ovary clavate; inflorescence dense. P. prismatocarpa

\section{TAXONOMY}

Prosthechea brassavolae (Rchb. f.) W.E. Higgins, Phytologia 82: 376. 1997. Epidendrum brassavolae Rchb. f., Bot. Zeit. 10: 729. 1852. Encyclium brassavolae (Rchb. f.) Lindl. ex Stein, Orchideenb. 224. 1892. Encyclia brassavolae (Rchb. f.) Dressler, Brittonia 13: 264. 1961. Hormidium brassavolae (Rchb.f.) Brieg., Die Orchideen 3, Aufl. 1: 576. 1977, nom. illeg.

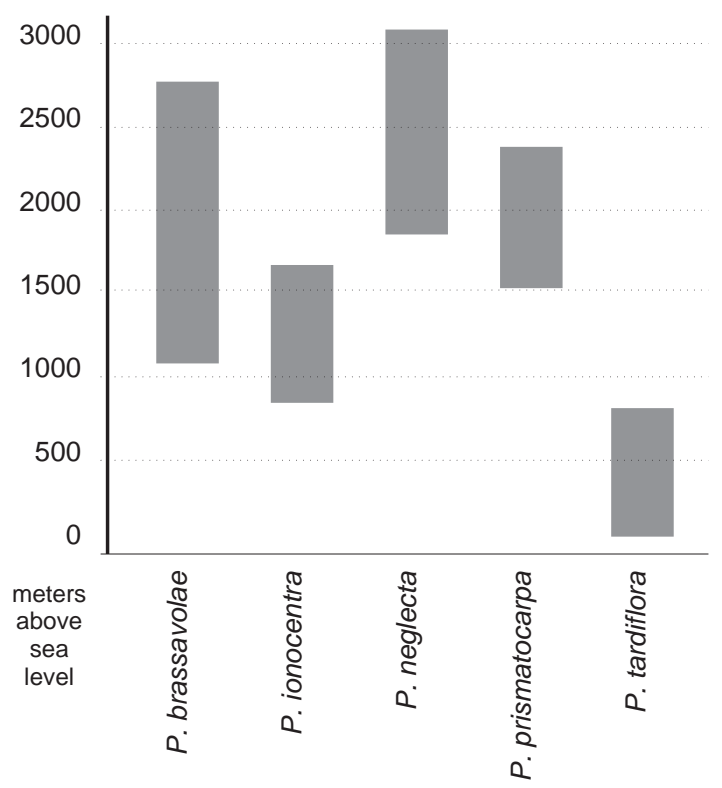

FIgURE 2. Altitudinal distribution of the Costa Rican species of Prosthechea prismatocarpa complex.
TYPE: Panama. Chiriquí Vulkan auf Steinen, 1000 ft., Warszewicz s.n. (W!).

Epiphytic in premontane to montane wet forest, at 1100-2700 m elevation. Mexico to western Panama. In Costa Rica it occurs on both drainages of Cordillera de Guanacaste, Tilarán and Talamanca. Flowering January to August.

Specimens seen: Costa RicA. Alajuela: Alto de La Palma de San Ramón, 1225 m, 6.XI.1923, A. M. Brenes 660 (CR!); La Palma de San Ramón, 1150 m, 26.VII.1924, $A$. M. Brenes 2228 (CR!); La Palma de San Ramón, 1150 m, 27.VIII.1925, A. M. Brenes 2547 (CR!); Monteverde, cerca de cumbre de loma, 1520-1590 m, 14.7.1977, V.J. Drier 1564 (CR!). Cartago: Turrialba, Tayutic, Vereh. Siguiendo la Fila entre Río Vereh y Río Jicotea, 8946'30"N 8332'40"W, 1500 m, 26 Jul. 1995, G. Herrera \& A. Cascante 8137 (CR!). Guanacaste: Monteverde, $3.4 \mathrm{~km} \mathrm{~N}$ of Santa Elena on road to Las Nubes, $10^{\circ} 22^{\prime} \mathrm{N} 84^{\circ} 49^{\prime} \mathrm{W}, 1500$ m, 14 Aug. 1988, $W$. Haber \& W. Zuchowski 8563 (INB!). Heredia: pastures near Río San Rafael, N.W. slopes of Barba Volcano, 1800 m, 17 Sept. 1967, R.W. Lent 1287 (CR!); Vara Blanca, 1400-1700 m, 27 June 1978, C. Todzia 331 (CR!); San Isidro, nov. 1989, D.E. Mora s.n. (USJ!). Puntarenas: Buenos Aires, cuenca Térraba-Sierpe, Estación Tres Colinas, 907'44'N 8303'58'"W, 1940 m, 9 Set. 1996, E. Alfaro 684 (INB!); Buenos Aires, P.N. La Amistad, cuenca Térraba-Sierpe, Puesto Tres Colinas, sendero casa Tipo A, 909'42"N 8304'01"W, 2550 m, 15 Set. 1996, B. Gamboa R. \& A. Picado 567 (INB!); Coto Brus, Reserva de la Biosfera de la Amistad; cerca Estación Biológica Las Alturas de Cotón, 857'00.3'N 8249'56.8'W, 1455 to 2100 m, 8.VII.1994, W.J. Kress \& K. Potgieter 94-5080 (CR!); Coto Brus, Z.P. Las Tablas, cuenca Térraba-Sierpe, fila a Cerro Burú, 900'32'N 8249'41'W, 2500-2700 m, 11 Ago. 1977, B. Gamboa \& E. Alfaro 1687 (CR!, INB!); Coto Brus, Las Alturas, camino al Cerro Echandi, 2100 m, 

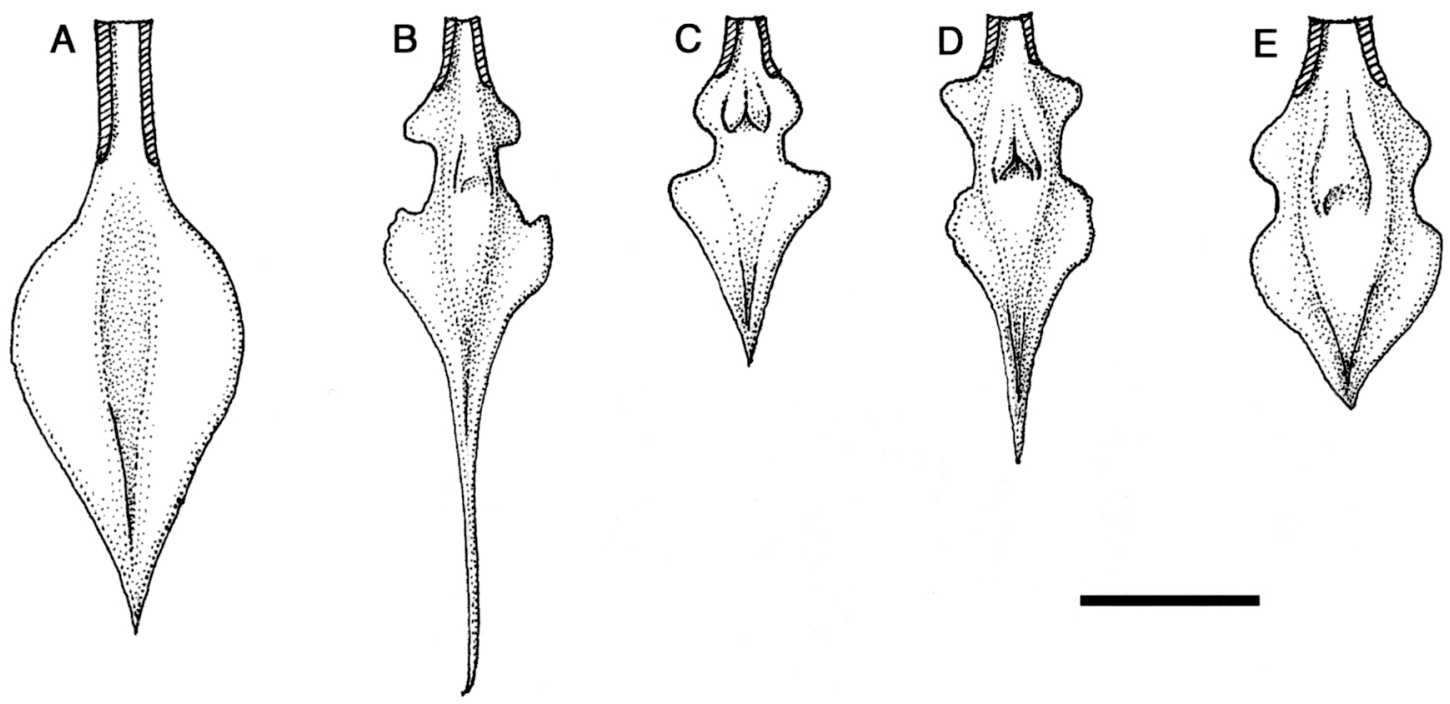

FIGURE 3. Comparison of lip shapes in Prosthechea prismatocarpa complex. A - P. brassavolae. B - P. ionocentra. C - P. neglecta. D - P. prismatocarpa. E - P. tardiflora. Bar $=1 \mathrm{~cm}$.

8 Jul. 1992, S. Martén 315 (USJ!); Coto Brus, Z.P. Las Tablas, cuenca Térraba-Sierpe, camino al Cerro Echandi, 900'20"N 8249'35'W, 2400-3160 m, 13 Abr. 1998, E. Alfaro 1602 (INB!); Coto Brus, Z.P. Las Tablas, Quijada del Diablo, 8'54'17'N 8245'03'W, 2050 m, 19 Nov. 1996, E. Navarro V., J.F. Quesada \& A. Rojas 524 (INB!); Coto Brus, Z.P. Las Tablas, cuenca Térraba-Sierpe, sendero a Cerro Echandi, en sub-paramo, 9 00 '32'N 82\%49'41"W, 2500-2700 m, 14 Ago. 1977, B. Gamboa R., E. Alfaro \& J.F. Quesada 1748 (INB!); Monteverde, Santa Elena, Valle de San Gerardo, 1300 m, 23 Enero 1999, floreció en cultivo, 13 Dec. 2000, M. Blanco \& V. Arias 963 (USJ!). Without collecting data, flowered in cultivation at Jardín Botánico Lankester, 8 July 1998, F. Pupulin 842 (USJ).

Prosthechea ionocentra (Rchb. f.) W.E. Higgins, Phytologia 82: 376. 1997. Epidendrum ionocentrum Rchb. f., Gard. Chron. n. s. 20: 8. 1883. Hormidium ionocentrum (Rchb.f.) Brieg., Die Orchideen 3, Aufl. 1: 576. 1977, nom. illeg. Epidendrum prismatocarpum Rchb.f. var. ionocentrum (Rchb.f.) Teuscher, Amer. Orch. Soc. Bull. 38: 398. 1969. Encyclia ionocentra (Rchb. f.) Mora-Retana \& J. García, Brenesia 33: 124. 1990. TYPE: (W!).

Epiphytic in premontane moist forest, at 900-1600 m elevation. Costa Rica and Panama. In Costa Rica it is restricted to the Cordillera de Tilarán. Flowering May to August.
Specimens Seen: Costa Rica. Alajuela: La Palma de San Ramón, pasture, 8 June 1969, R.W. Lent 1721 (CR!); San Ramón, Monteverde, San Gerardo Biological Station, $1.5 \mathrm{~km} \mathrm{NE}$ of Station, $10^{\circ} 22^{\prime} 00^{\prime \prime} \mathrm{N} 84^{\circ} 47^{\prime} 00^{\prime \prime} \mathrm{W}, 900 \mathrm{~m}, 20$ July 1995, D. Penneys 605 (CR!). Guanacaste: Monteverde, $3.4 \mathrm{~km} \mathrm{~N}$ of Santa Elena on road to Las Nubes, $10^{\circ} 22^{\prime} \mathrm{N} 84^{\circ} 49^{\prime} \mathrm{W}, 1500 \mathrm{~m}, 14$ Aug. 1988, $W$. Haber \& W. Zuchowski 8559 (INB!). Puntarenas: Monteverde, Bullpen, $10^{\circ} 18^{\prime} \mathrm{N} 84^{\circ} 47^{\circ} \mathrm{W}$, ca. $1550 \mathrm{~m}$, on remnants of primary forest in pastures, 16 July 1998, $F$. Pupulin 880, D.E. Mora G. Barboza \& Curso de Orquideología (USJ); without collecting data: flowered in cultivation at Jardín Botánico Lankester, 17 June 1998, F. Pupulin 748 (USJ); cult. Oscar Blanco, 27 Junio 1971, R.L. Rodriguez C. 1283 (USJ!).

Prosthechea neglecta Pupulin, Selbyana 22: 21. 2001. TYPE: Costa Rica. San José: Dota, San Pedro, ca. 1900 m, M. Flores s.n. (USJ!).

Epiphytic or lithophytic in montane wet forest, at 1900-2800 m elevation. Only known from Costa Rica, where it is restricted to the upper Pacific slopes of the Cordillera de Talamanca. Flowering March to June.

Other specimens Seen: Costa Rica. San José: Pérez Zeledón, Alcoa, collected by J. Cambronero, March 1994, flowered in cltivation at Jardín Botánico Lankester, 12 May 1998, F. Pupulin 616 (USJ). Without collecting data, flowered in cultivation in the collection of G. Pozzi, June 1997 (Photo!). 

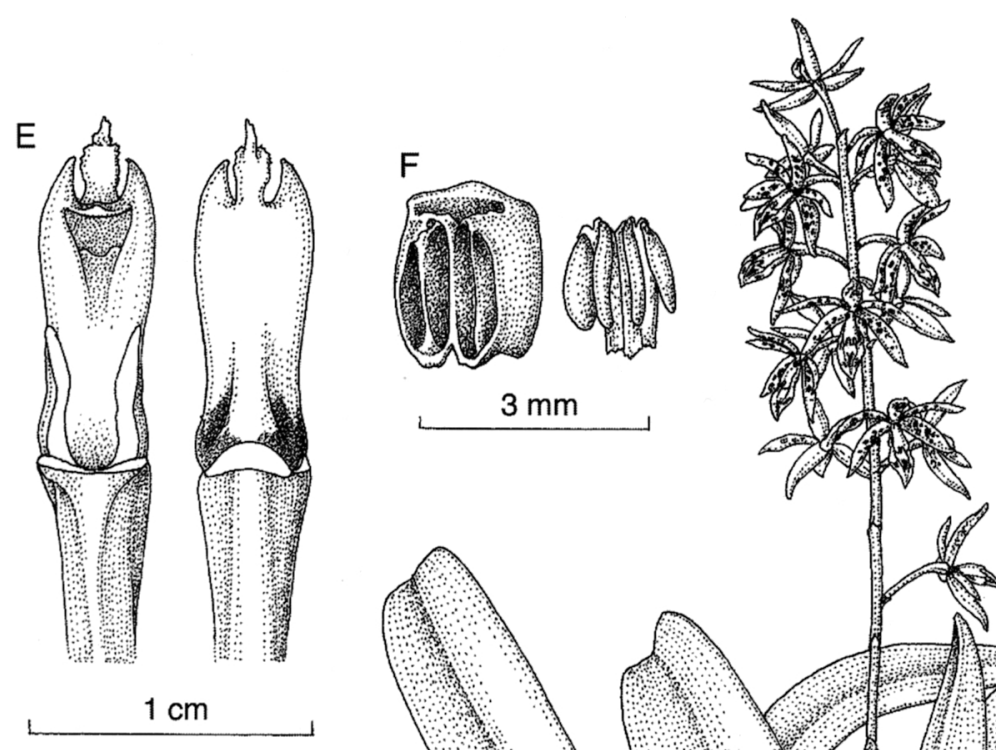

A
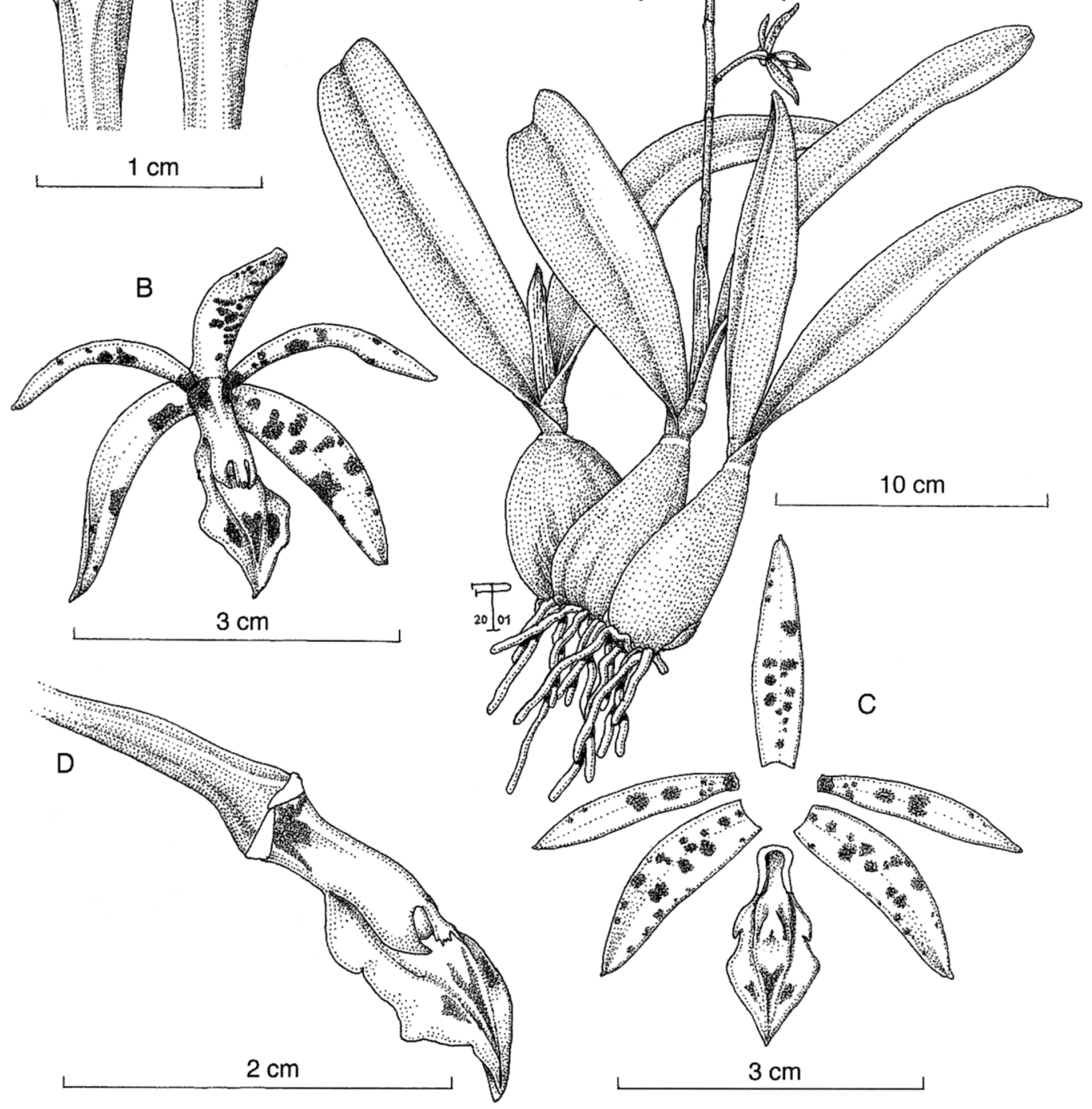
Prosthechea prismatocarpa W.E. Higgins, Phytologia 82: 376. 1997. Epidendrum prismatocarpum Rchb. f., Bot. Zeit. 10: 729. 1852. Encyclia prismatocarpa (Rchb. f.) Dressler, Brittonia 13: 265. 1961. Hormidium prismatocarpum (Rchb.f.) Brieg., Die Orchideen 3, Aufl. 1: 574. 1977, nom. illeg. TYPE: PANAMA. Chiriqui Vulcan. November. $8000 \mathrm{ft}$, Warszewicz s.n. (W!).

Epiphytic in lower montane and montane moist forest, at (100) 1500-2400 m elevation. Costa Rica and western Panama. In Costa Rica it is known from the Pacific slopes of Cordillera Central. Flowering April to August.

Specimens SEen: Costa Rica. Alajuela: Monteverede, 15.5.1987, A. Ruiz Boyer 2 (USJ!). Cartago: alrededores de Reserva Tapantí, 6.6.1987, C.M. Centeno P. 9 (USJ!); Turrialba, alto Pacuare, $100 \mathrm{~m}, 21.7 .1978$, R.A. Ocampo $S$. 2356 (CR!). Heredia: arriba de San José de la Montaña, Río Porrós, barba, 1900 m, Junio 26, 1965, A. Jiménez M. 3252 (CR!); San Isidro, ca. 1600 m, flor. 26.2.1994, $L$. Jiménez s.n. (USJ!). Puntarenas: Reserva Monteverde, 15.5. 1987, G. Nuñez R. 1 (USJ!). San José: Carrillo, Río Patria, 26.6.1933, Series de varios colectores 194 (CR!); Carretera Interamericana Sur, camino a La Georgina, 26.4.1987, G. Vargas 302 (USJ!); Laderas del Cerro Chirripó Grande, 24 Junio 1967, A.S. Weston 1063 (USJ!); Alajuelita, Z.P. Cerros de Escazú, cuenca del Río Grande de Tárcoles, Cerro Rabo de Mico, 9 $9^{\circ} 50^{\prime} 50^{\prime \prime N} 84^{\circ} 08^{\prime} 15^{\prime}$ 'W, 2420 m, 27 Nov. 1993, J.F. Morales 2111 (INB!).

Prosthechea tardiflora Mora-Retana ex Pupulin, sp. nova

FIG. 4.

TYPE: Costa RicA. Guanacaste: Santa Cruz, from Juan Día toward Vista al Mar, 500-600 m, collected by Raúl Cascante Arias, 1992, flowered in cultivation at Tambor de Alajuela, 15 January 2001, F. Pupulin 2806 (holotype, USJ!).

Herba epiphytica Prosthecheae prismatocarpae (Rchb.f.) W.E. Higgins similis, rhizoma perbrevi, pseudobulbis complanatis ovatis vel suborbicularis, inflorescencia a caule anni praecedenti producta, labello obovato-subpandurato, isthmo lato, lobo mediano breviter triangulari, callo lamina plana vescicula antice binata superposita recedit.

Plant epiphytic, with a very short rhizome covered by papyraceous, brown bracts. Roots flexuous, glabrous. Pseudobulbs ovate to broadly ovate to suborbicular, laterally complanate, $6.2-8.0 \mathrm{~cm}$ long, $3.4-5.0 \mathrm{~cm}$ wide, 2 - to rarely 3 -foliate at apex. Leaves separate by an internode to $1.4 \mathrm{~cm}$ long, narrowly elliptic to liner-elliptic, fleshy, obtuse to retuse, narrowed to a conduplicate, subsessile base, 15-18 cm long, 3-4 cm wide. Inflorescence terminal, an erect, dense raceme produced from the apex of the previous pseudobulb, to $27 \mathrm{~cm}$ long including the peduncle, many-flowered, emerging from a papery bract to $8 \mathrm{~cm}$ long. Ovary subclavate, sligtly winged, about $2.5 \mathrm{~cm}$ long including the pedicel. Flowers rather large, with sepals and petals free, spreading, yellowish cream to ochre, the sepals and petals spotted with purple, the lip cream white with three rose-purple blotches. Dorsal sepal narrowlylanceolate, acute, somewhat reflexed at the base, adaxially verruculose, to $23 \mathrm{~mm}$ long, $5 \mathrm{~mm}$ wide. Lateral sepals obliquely lanceolate, subfalcate, minutely apiculate, dorsally subcarinate and slightly concave toward the apex, convex at the base, 22 $\mathrm{mm}$ long, $6.5 \mathrm{~mm}$ wide. Petals linear-elliptic, acute, $22 \mathrm{~mm}$ long, $3.5 \mathrm{~mm}$ wide. Lip 3-lobed, obovate-subpandurate, the basal claw adnate to the column, $20 \mathrm{~mm}$ long, $9.5 \mathrm{~mm}$ wide; the lateral lobes rounded to subfalcate; the midlobe ovate-triangular, acute, concave toward the apex; disc with a callus formed by a flat lamina with a fleshy vescicle bifurcate at apex. Column stout, semiterete, $13 \mathrm{~mm}$ long, provided at the apex with a pair of fleshy, subfalcate, acute lateral teeth, and a central, lacerate-dentate projection. Anther cap incumbent, operculate, subquadrate to subspherical, 4-celled. Pollinia 4, waxy, narrowly obovate, complanate, on two short, linear, shortly bifid caudicles.

Paratypes: Costa Rica. Alajuela: Palmares, orillas del Río Rastrojos, en floración el 26/II/1994, $W$. Barahona s.n. (USJ!); Palmares, a orillas del Río Jesús María, Marzo de 1994, D.E. Mora s.n. (USJ!). Puntarenas: Aguirre, Villa Nueva, Finca Walker, about $200 \mathrm{~m}$, collected by Mrs. Merli, flowered in cultivation at Gaia Botanical Garden, 20 Apr. 1999, F. Pupulin 1431 (USJ, Spirit!).

DistRIBUTION: only known from Costa Rica.

Ecology And Phenology: epiphytic in rain and seasonally moist forests along the Pacific drainage, 
usually restricted to lowlands and premontane warm areas at 200-800 m elevation. Flowering occurs from January to April.

ETymology: from the Latin tardiflorus, "late-flowering," in allusion to the flowering habit of the species, with the inflorescence emerging from the pseudobulb of the previous year.

The occurrence in Costa Rica of an undescribed species closely related to $P$. prismatocarpa was first noted by the late Dora Emilia Mora-Retana, who accordingly annotated two specimens kept in the herbarium of the Escuela de Biología, Universidad de Costa Rica (USJ) with the proposed epythet "Encyclia tardiflora" (Morales 2001). Recording the presence of $P$. prismatocarpa in Costa Rican central Pacific lowlands, Pupulin (2001a) noted several characters useful to distinguish lowlands populations from typical forms of the species as occurring above $1000 \mathrm{~m}$ elevations, among which the abbreviate rhizome, the inflorescence produced on the previous pseudobulb, the non-fragrant flowers, the acute and basally reflexed sepals. It is obvious now that these populations, as well as the plant illustrated by Pupulin (2001a) should be assigned to $P$. tardiflora.

Other close relatives of $P$. tardiflora are $P$. ionocentra, and $P$. neglecta. However, the flowers of $P$. ionocentra lack purple spots, the sepals and petals are distinctly longer $(>4 \mathrm{~cm}$ vs. $<2 \mathrm{~cm}$ long in $P$. tardiflora) and thecordate-sagittate midlobe of the lip is caudate at apex (Mora-Retana \& GarcíaCastro 1990). On the other hand, P. neglecta presents a very long rhizome, narrowly ovate to linearconic pseudobulbs, laxe inflorescence and adaxially papillose sepals (Pupulin 2001b).
AcKnowledgements. I thank Robert L. Dressler and the late Dora Emilia Mora-Retana for their useful observations on the complex discussed here. Wesley H. Higgins provided information about type collections. Sincere acknowledgements are extended to the staff of Jardín Botánico Lankester, Universidad de Costa Rica, for the support provided to my studies.

\section{LITERATURE CITED}

Atwood, J.T. \& D.E. Mora-Retana. Orchids of Costa Rica, part 2. Icon. Pl. Trop. 15: pl. 1427.

Dressler, R.L. 1993. Field guide to the orchids of Costa Rica and Panama. Cornell University Press, Ithaca and London.

Espejo Serna, A. \& A.R. López-Ferrari. 1997. Las monocotiledóneas mexicanas. Una sinopsis florística. 1. Lista de referencia. Parte VII. Orchidaceae (1). Consejo Nacional de la Flora de México, Mexico.

Mora-Retana, D.E. \& J.T. Atwood 1992. Orchids of Costa Rica, Part 2. Icon. Pl. Trop. 15: sub pl. 1427.

Mora-Retana, D.E. \& J. García-Castro 1990. Nuevas combinaciones de Orchidaceae de Costa Rica. Brenesia 33: 123-126.

Morales, C.O. 2001. Dora Emilia Mora de Retana, 19402001. Lankesteriana 2: 1-7.

Pupulin, F. 2001a. Addenda Orchidaceis Quepoanis. Lankesteriana 1: 1-28.

2001b. Miscellaneous new taxa in Neotropical Orchidaceae. Selbyana 22: 14-26.

Reichenbach, H.G. 1883. Epidendrum prismatocarpum. Xenia Orch. 2: 83, t. 123.

1886. Orchidaceae Warscewiczianae. Beiträge zu einer Orchideenkunde Central-Amerika's. Hamburg. p.34-35.

Schlechter, R. 1923. Orchidaceae Bradeanae Costaricenses. Repert. Sp. Nov. Regni Veg. Beih. 19: 117.

Teuscher, H. 1969. Epidendrum prismatocarpum var. ionocentrum. Amer. Orch Soc. Bull. 48(5): 395-398. 